Bentham OPEN
CrossMark
Content list available at: www.benthamopen.com/TODENTJ/
DOI: $10.2174 / 1874210601610010454$

RESEARCH ARTICLE

\title{
Local Anaesthetic Drug Administration in Dentistry Using Computer Assisted Anaesthetic Delivery System: A Systematic Review
}

\author{
Gowri Sivaramakrishnan ${ }^{*}, 1$ and Kannan Sridharan ${ }^{2}$ \\ ${ }^{\text {I}}$ Department of Oral Health, Fiji National University, Suva, Fiji \\ ${ }^{2}$ Department of Pharmacology, Fiji National University, Suva, Fiji
}

Received: January 05, 2016

Revised: July 20, 2016

Accepted: July 23, 2016

\begin{abstract}
:
Background:

Local anaesthetics play a key role in reducing pain and anxiety during dental treatment. However the disadvantage of using syringe and needle technique in the maxilla, proximal to the apices of the teeth is that it is painful and also leads to collateral anaesthesia. Hence this systematic review aims to identify whether computer assisted local anaesthetic delivery system could produce predictable results similar to conventional syringe needle technique and also eliminate the disadvantages.
\end{abstract}

\section{Method:}

Electronic databases were searched for eligible studies. A pre-tested data extraction form was created and following data were extracted from each eligible study: trial site, year, trial methods, participants, interventions and outcomes. A significant heterogeneity was seen in between the eligible studies.

\section{Results:}

Six studies met the inclusion criteria and were included in the present review. One was cross-over and one split mouth, while others were parallel. Only one was open label and the rest were single blinded. Three studies were conducted in children while the rest in adults. The outcome measurement was directed to measure psychological attributes using visual analog scale, electric pulp testing and pain behaviour code.

\section{Conclusion:}

Unfortunately because of the clinical heterogeneity, meta-analysis could not be performed. Hence it is difficult to conclude that the computer assisted delivery is better than the conventional method, although it was found to perform better. Many high quality studies assessing the efficacy and cost-efficiency of various modes of administration are required to confirm the utility of computer assisted delivery systems.

Keywords: Computer assisted anaesthesia, Dental anxiety local anaesthesia, Maxillary anaesthesia, Maxilla, Pain.

\section{INTRODUCTION}

Pain is the most common cause of fear and anxiety in dental practice. Local anaesthetics play a key role in reducing pain and anxiety and are used with or without epinephrine in specified concentrations for various dental procedures. [1, 2] As regards the maxillary anaesthesia, supraperiosteal injections into the mucobuccal fold, proximal to the apices of the teeth using conventional syringe and needle have been commonly used. However certain instances may warrant multiple needle penetrations for adequate pulpal anaesthesia, which increased the dose and caused collateral anaesthesia

\footnotetext{
* Address correspondence to this author at the Department of Oral Health, College of Medicine, Nursing and Health Sciences, Hoodless House, Brown Street, Suva, Republic of Fiji; Tel: +679 9090572; E-mail: gowri.sivaramakrishnan@gmail.com
} 
$[3,4]$. In the mid-1990s, the computer assisted system has been developed which provided predictable pulpal anaesthesia of multiple maxillary teeth from a single injection, minimizing the dose with minimal or reduced risk of collateral anaesthesia. It incorporated computer technology to control the rate of flow of the anaesthetic solution through the needle. This concept was called computer-controlled local anaesthetic delivery (CCLAD) [5, 6]. It has a foot control that automates at precise pressure and volume rates which control the drug being delivered. It could be used for buccal, palatal, intraligamental infiltration and blocks. Some of the commercially available CCLADs are Wand, Wand plus and Compumed. Anterior middle superior alveolar (AMSA) and Palatal anterior superior alveolar (P-ASA) techniques are most frequently used with the computer assisted system. [7 - 9] Besides the introduction of the technique, a systematic compilation on studies does not exist. Hence this systematic review aims to identify the use of computer-assisted local anaesthetic technique in producing predictable anaesthesia as conventional syringe needle technique, eliminating the disadvantages.

\section{METHOD}

\section{Information Sources and Search Strategy}

The protocol for this review was registered with International prospective register of systematic reviews (PROSPERO) with the registration number CRD42015032590. The review protocol can be accessed at http://www.crd.york.ac.uk/PROSPERO/display_record.asp?ID=CRD42015032590. Literature search was conducted using key words computer controlled anaesthesia [tiab] and was completed on 23 Dec 2015. The primary data base used was Medline (via PubMed), Cochrane central register of clinical trials (CENTRAL) and Database of Abstracts of Reviews of Effects (DARE). This search was further supplemented by hand searching of relevant references from review articles and other eligible studies. No limits were applied to the year of study but only studies published in English language were included.

\section{Eligibility Criteria}

Only those studies with randomized controlled design with the following requirements were included in the present study:

1. Type of participants - Adults/children requiring infiltration or block local anaesthesia for dental procedures in the maxillary arch

2. Types of intervention - Any local anaesthetic drug administration in the maxillary arch using computer assisted delivery system

3. Comparison - Any local anaesthetic administration in the maxillary arch using traditional needle technique or using a computer assisted system

4. Outcome - Assessment of the efficacy of local anaesthetic using electric pulp testing, assessment of pain using VAS, assessment of behaviour using behaviour codes

\section{Study Procedure}

Both the authors independently screened the above mentioned data bases for studies and independently reviewed abstracts for suitability. Full-texts articles were obtained for those found to be eligible to be included and for those that were inconclusive on the abstract screening. A pre-tested data extraction form was created and both the authors independently extracted the following data from each eligible study: trial site, year, trial methods, participants, interventions, and outcomes. Disagreement between the authors was resolved through discussion. A significant heterogeneity was seen in between the eligible studies. The present meta-analysis was conducted and presented in accordance with Preferred Reporting Items for Systematic Reviews and Meta-Analyses (PRISMA) guidelines. [10, 11].

\section{RESULTS}

\section{Search Results}

A total of 39 articles were identified, of which 12 was shortlisted on title screening. Of the 12, two assessed the efficacy of different local anaesthetic agents delivered using CCLAD, one was not randomized and three were on healthy patients that assessed pain due to injection technique only. After full text and abstract screening, six studies met the inclusion criteria and were included in the present review. The study flow chart is shown in Fig. (1). 


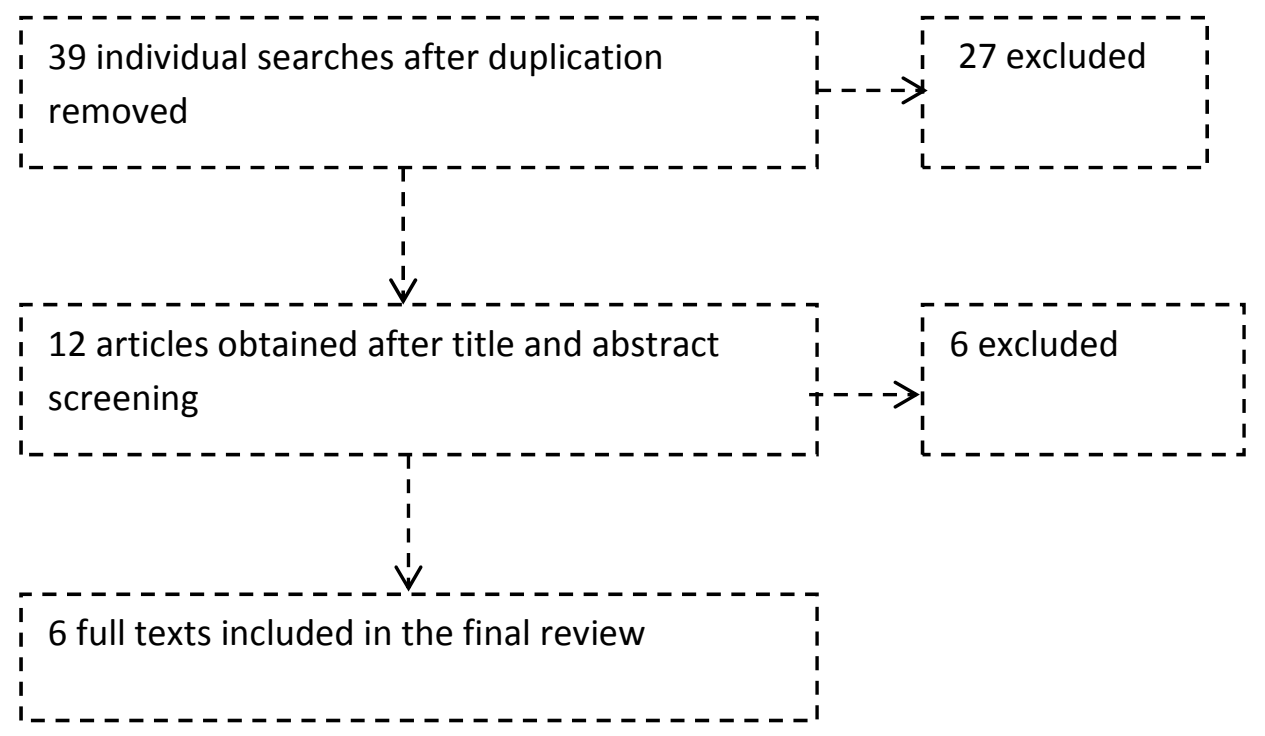

Fig. (1). Study flow chart.

\section{Key Features of Included Studies}

Six studies [12 - 17] were found to be eligible to be included. Of these six studies, one was cross-over [13], one split mouth [14] while all others were parallel group studies. Only one [12] was open label and the rest five [13 - 17] were single blinded. Three studies $[12,15,17]$ were conducted in children while the rest in adults $[13,14,16,17]$. The outcome measurement was directed to psychological attributes in two studies [12, 15, 17], visual analog scale in four studies [12, 13, 15, 16] and electric pulp testing in Kandiah et al. [16]. Other salient features of the included studies are listed in Table 1. Due to significant clinical heterogeneity between the included studies, meta-analysis was not carried out. But considering all the included studies, the computer assisted technique performed better than the conventional syringe needle technique for administration of local anaesthetic in terms of pain measured using VAS, psychological attributes and predictable anaesthesia achieved which was measured using electric pulp testing. Risk of bias of the included studies was assessed as per Cochrane's risk of bias tool [10] and is depicted in Fig. (2).

Table 1. List of included studies.

\begin{tabular}{|c|c|c|c|c|c|c|}
\hline \multirow{3}{*}{$\begin{array}{l}\text { Study; } \\
\text { Type of } \\
\text { Study: }\end{array}$} & \multirow[t]{3}{*}{ Participants } & \multirow[t]{3}{*}{ Intervention } & \multirow[t]{3}{*}{ Control } & \multicolumn{3}{|c|}{ Outcome } \\
\hline & & & & \multirow{2}{*}{$\begin{array}{c}\text { Outcome } \\
\text { measure used }\end{array}$} & \multicolumn{2}{|c|}{ Numerical values } \\
\hline & & & & & $\begin{array}{c}\text { Intervention } \\
\text { Group }\end{array}$ & $\begin{array}{l}\text { Control } \\
\text { Group }\end{array}$ \\
\hline \begin{tabular}{|} 
Klein et al. \\
{$[12]$} \\
RCT; open \\
label; parallel \\
group
\end{tabular} & $\begin{array}{c}21 \text { children of } 3-5 \text { years } \\
\text { of age who required } \\
\text { pulp tissue removal and } \\
\text { subsequent } \\
\text { crown/extraction for at } \\
\text { least two teeth in the } \\
\text { anterior maxillary } \\
\text { segment on opposite } \\
\text { sides of the midline }\end{array}$ & $\begin{array}{c}\text { P-ASA with CompuMed- } \\
1.4 \mathrm{ml} \text { of } 2 \% \text { lignocaine } \\
\text { with 1:100,000 epinephrine }\end{array}$ & $\begin{array}{c}\text { Several buccal infiltrations } \\
\text { and an additional palatal } \\
\text { injection- Traditional syringe- } \\
2 \% \text { lignocaine with } 1: 100,000 \\
\text { epinephrine in } 1.8 \mathrm{ml} \text { cartridge } \\
\text { with a } 30 \text {-gauge needle }\end{array}$ & $\begin{array}{c}\text { Disruptive } \\
\text { behaviour } \\
\text { using anxious } \\
\text { and disruptive } \\
\text { behaviour } \\
\text { code }\end{array}$ & $\begin{array}{l}50 \% \text { disruptive } \\
\text { behaviour, } \\
30 \% \text { crying and } \\
28 \% \text { body } \\
\text { movement were } \\
\text { observed }\end{array}$ & $\begin{array}{c}75 \% \\
\text { disruptive } \\
\text { behaviour, } \\
57 \% \text { crying } \\
\text { and } \\
49 \% \text { body } \\
\text { movement } \\
\text { were } \\
\text { observed }\end{array}$ \\
\hline $\begin{array}{l}\text { Loomer PM } \\
\text { et al. }[13] \\
\text { RCT, single } \\
\text { blind, cross } \\
\text { over design }\end{array}$ & $\begin{array}{c}20 \text { adults with } \\
\text { moderate periodontal } \\
\text { disease requiring } \\
\text { scaling and root } \\
\text { planning }\end{array}$ & $\begin{array}{c}\text { AMSA and P-ASA using } \\
\text { 2\% lignocaine with } \\
\text { 1:100,000epinephrine. }\end{array}$ & $\begin{array}{c}\text { PSA,MSA,ASA,GP,NP using } \\
2 \% \text { lignocaine in } 1: 100,000 \\
\text { epinephrine }\end{array}$ & $\begin{array}{l}\text { Visual analog } \\
\text { scale (VAS) }\end{array}$ & $\begin{array}{c}\text { A mean (SD) } \\
\text { difference of } 0.19 \\
(0.24) \text { was } \\
\text { observed in VAS } \\
\text { from baseline }\end{array}$ & $\begin{array}{c}\text { A mean }(\mathrm{SD}) \\
\text { difference of } \\
0.22(0.24) \\
\text { was observed } \\
\text { in VAS from } \\
\text { baseline }\end{array}$ \\
\hline
\end{tabular}




\begin{tabular}{|c|c|c|c|c|c|c|}
\hline \multirow{3}{*}{$\begin{array}{l}\text { Study; } \\
\text { Type of } \\
\text { Study: }\end{array}$} & \multirow[t]{3}{*}{ Participants } & \multirow[t]{3}{*}{ Intervention } & \multirow[t]{3}{*}{ Control } & \multicolumn{3}{|c|}{ Outcome } \\
\hline & & & & \multirow{2}{*}{\begin{tabular}{c|} 
Outcome \\
measure used
\end{tabular}} & \multicolumn{2}{|c|}{ Numerical values } \\
\hline & & & & & $\begin{array}{l}\text { Intervention } \\
\text { Group }\end{array}$ & $\begin{array}{l}\text { Control } \\
\text { Group }\end{array}$ \\
\hline $\begin{array}{c}\text { Yenisey M } \\
{[14]} \\
\text { RCT, single } \\
\text { blinded study } \\
\text { using split } \\
\text { mouth design }\end{array}$ & $\begin{array}{c}16 \text { adult patients aged } \\
27 \text { to } 64 \text { years, with } \\
\text { partially edentulous } \\
\text { state in both right and } \\
\text { left maxilla to undergo } \\
\text { fixed prosthodontics } \\
\text { treatment }\end{array}$ & $\begin{array}{c}\text { AMSA using Wand at } 1.7 \\
\text { ml articaine hydrochloride } \\
\text { with } 0.006 \mathrm{mg} \text { adrenaline } \\
\text { using } 27 \mathrm{G} \text { needle }\end{array}$ & $\begin{array}{c}2 \mathrm{ml} \text { articaine hydrochloride } \\
\text { with } 0.006 \mathrm{mg} \text { adrenaline } \\
\text { with } 27 \mathrm{G} \text { needle with a } \\
\text { plastic syringe }\end{array}$ & $\begin{array}{l}\text { Verbal rating } \\
\text { scale (VRS) }\end{array}$ & $\begin{array}{l}\text { Median (range) of } \\
\text { VRS was } 0(0-2)\end{array}$ & $\begin{array}{c}\text { Median } \\
\text { (range) of } \\
\text { VRS was } 2 \\
(0-3)\end{array}$ \\
\hline $\begin{array}{l}\text { Tahmassebi et } \\
\text { al. }[15] \\
\text { RCT; single } \\
\text { blinded; } \\
\text { parallel group }\end{array}$ & $\begin{array}{l}38 \text { children of age } \\
39-120 \text { months in need } \\
\text { of at least one } \\
\text { restoration on either } \\
\text { side of maxilla }\end{array}$ & $\begin{array}{l}\text { Wand assisted buccal } \\
\text { infiltration and direct } \\
\text { palatal injection of } 2 \% \\
\text { lignocaine in 1:80000 } \\
\text { adrenaline }\end{array}$ & $\begin{array}{c}\text { Buccal and intra papillary } \\
\text { infiltration using } 2 \% \\
\text { lignocaine in 1:80000 } \\
\text { adrenaline }\end{array}$ & $\begin{array}{l}\text { The anxiety } \\
\text { using Venham } \\
\text { scale and } \\
\text { modified } \\
\text { VAS for pain }\end{array}$ & $\begin{array}{l}\text { Mean (SD) of } \\
\text { anxiety score - } \\
1.7(2.5) \text { and } \\
32.1(30.8) \text { for } \\
\text { VAS }\end{array}$ & $\begin{array}{l}\text { Mean (SD) of } \\
\text { anxiety score - } \\
1.5(1.9) \text { and } \\
29.4(22.4) \text { for } \\
\text { VAS }\end{array}$ \\
\hline $\begin{array}{c}\text { Kandiah et al. } \\
\text { [16] } \\
\text { RCT; single } \\
\text { blinded; } \\
\text { parallel group }\end{array}$ & $\begin{array}{l}30 \text { individuals of } 8-16 \\
\text { years with minimal } \\
\text { caries requiring } \\
\text { restoration of upper } \\
\text { first permanent molar } \\
\text { tooth }\end{array}$ & $\begin{array}{c}\text { Wand assisted infiltration } \\
\text { using } 1.8 \mathrm{ml} \text { of } 2 \% \\
\text { lignocaine in } 1: 80000 \\
\text { adrenaline }\end{array}$ & $\begin{array}{l}\text { Traditional syringe assisted } \\
\text { infiltration of } 1.8 \mathrm{ml} \text { of } 2 \% \\
\text { lignocaine in 1:80000 } \\
\text { adrenaline }\end{array}$ & \begin{tabular}{|c|} 
Onset of \\
anaesthesia \\
measured by \\
Electric pulp \\
testing; \\
Pain \\
measured by \\
modified \\
visual analog \\
scale
\end{tabular} & \begin{tabular}{|c|} 
Mean (SD) \\
of onset of \\
anaesthesia was \\
$6.8(3.1)$ \\
and $14 / 15$ had \\
no pain
\end{tabular} & $\begin{array}{l}\text { Mean (SD) of } \\
\text { onset of } \\
\text { anaesthesia was } \\
6.1(2.7) \text { and } \\
12 / 14 \text { had no } \\
\text { pain }\end{array}$ \\
\hline $\begin{array}{l}\text { Allen et al. } \\
\quad[17] \\
\text { RCT; single } \\
\text { blinded; } \\
\text { parallel group }\end{array}$ & $\begin{array}{l}40 \text { patients } 2-5 \text { years of } \\
\text { age needing operative } \\
\text { dentistry in maxilla }\end{array}$ & $\begin{array}{c}\text { Wand assisted AMSA or P- } \\
\text { ASA of } 1.4 \mathrm{ml} 2 \% \\
\text { lignocaine with } 1: 100000 \\
\text { epinephrine using } 30 \mathrm{G} \\
\text { needle }\end{array}$ & $\begin{array}{c}\text { Traditional } 1 \mathrm{ml} \text { buccal } \\
\text { infiltration and } 0.18 \mathrm{ml} \text { palatal } \\
\text { injection of } 2 \% \text { lignocaine } \\
\text { with } 1: 100000 \text { epinephrine } \\
\text { using } 30 \mathrm{G} \text { needle }\end{array}$ & $\begin{array}{c}\text { Any } \\
\text { disruptive } \\
\text { behaviour; } \\
\text { Crying; Body } \\
\text { movement } \\
\text { and restraint }\end{array}$ & \begin{tabular}{|c|}
$50 \%$ had \\
disruptive \\
behaviour; $30 \%$ \\
had crying \\
spells; $28 \%$ had \\
body movement \\
and 3\% \\
restraint
\end{tabular} & $\begin{array}{c}71 \% \text { had } \\
\text { disruptive } \\
\text { behaviour; } 57 \% \\
\text { had crying } \\
\text { spells; } 49 \% \text { had } \\
\text { body movement } \\
\text { and } 34 \% \\
\text { restraint }\end{array}$ \\
\hline
\end{tabular}

Risk of bias of the included studies in the systematic review.

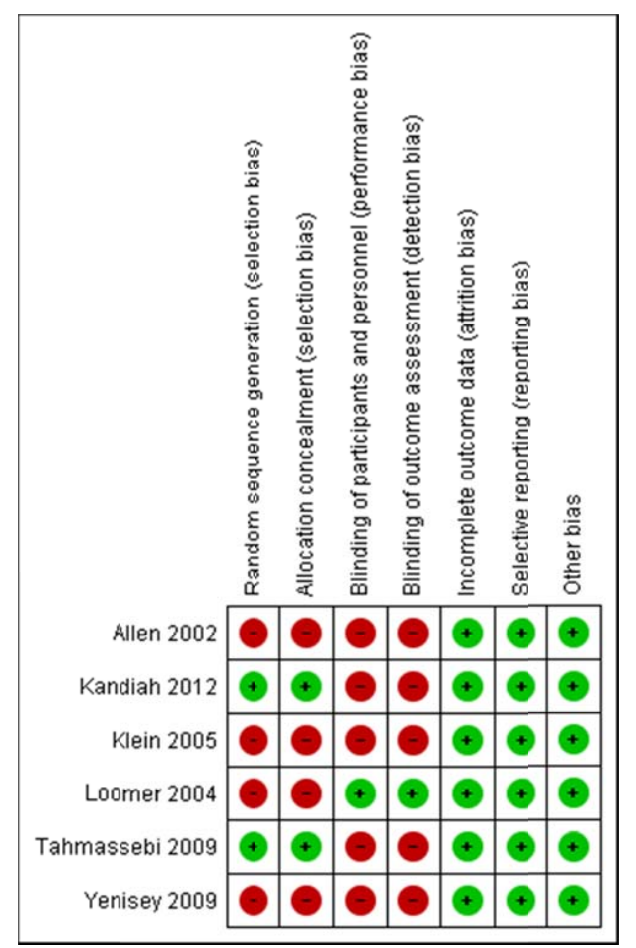

Fig. (2). Red circle with minus symbol indicates the absence of reporting of that element by the authors while green circle with plus symbol indicates that the authors have reported the same in their study. 


\section{DISCUSSION}

Anxiety and fear form the mainstay of deferral in patients undergoing dental treatment, especially involving the injection of local anaesthetics. Recent advances in the field of dental local anaesthesia has come up with the computer controlled anaesthetic delivery vehicle which acts by regulating the rate of flow and delivery of the anaesthetic agent, thereby decreasing the amount of discomfort produced. Additionally the undesired extra oral soft tissue anaesthesia can be eliminated. For the local anaesthetic to provide the required depth of anaesthesia, they must be injected. The main problem lies in the needle and not the cartridge or the syringe. Dental needles are usually 25, 27 or 30 gauges, however the perception remains indistinguishable [18]. Unfortunately this ability to provide painless injection is considered one important factor by patients in selecting their dentist [19]. The Computer -controlled local anaesthetic delivery (CCLAD) was introduced in the mid-1990. A light weight handpiece in a pen like grasp delivers the drug with a footactivated control. The flow rate of the drug is controlled by the computer, which provides consistent injection from one

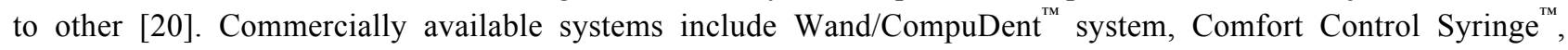
QuickSleeper $^{\mathrm{TM}}$ and Anaeject ${ }^{\mathrm{TM}}$.

The maxillary palatal injections are considered to be the most painful because of the mucosal binding to the underlying periosteum and its abundant nerve supply. The pain caused is mainly as a result of displacement of the mucoperiosteum rather than the needle penetration [21]. The introduction of computer assisted system would definitely be of much value in reducing significant discomfort caused due to traditional needle injection technique theoretically. Many individual randomized controlled studies of high quality, which are included in this review, have tested the newer method of delivery of LA (CCLAD) and identified it to be more effective than conventional [12 - 17]. Unfortunately because of the clinical heterogeneity amongst the studies, a synthetic meta-analysis could not be performed. Hence, at the moment it is difficult to conclude that use of computer assisted delivery is superior to the conventional method, although it was found to perform better from individual studies. More such high quality studies assessing the efficacy and cost-efficiency of various modes of administration are required to confirm the utility of computer assisted delivery systems.

\section{CONFLICT OF INTEREST}

The authors confirm that this article content has no conflict of interest.

\section{ACKNOWLEDGEMENTS}

Declared none.

\section{REFERENCES}

[1] Bahl R. Local anesthesia in dentistry. Anesth Prog 2004; 51(4): 138-42. [PMID: 15675263]

[2] Haas DA. An update on local anesthetics in dentistry. J Can Dent Assoc 2002; 68(9): 546-51. [PMID: 12366885]

[3] Yagiela JA. Local anesthetics. In: Dionne RA, Phero JC, Becker DE, Eds. Pain and anxiety control in dentistry. Philadelphia: W. B. Saunders 2002; pp. 78-96.

[4] Haas DA. Drugs in dentistry. In: Compendium of pharmaceuticals and specialties (CPS). 37 ${ }^{\text {th }}$ ed. Canada: Canadian Pharmaceutical Association 2002; pp. L26-9.

[5] United States Pharmacopeial Drug Information Index. Greenwood Village. $22^{\text {nd }}$ ed. Colorado: Micromedex 2002.

[6] Yagiela JA. Adverse drug interactions in dental practice: interactions associated with vasoconstrictors. Part V of a series. J Am Dent Assoc 1999; 130(5): 701-9. [http://dx.doi.org/10.14219/jada.archive.1999.0280] [PMID: 10332135]

[7] Friedman MJ, Hochman MN. The AMSA injection: a new concept for local anesthesia of maxillary teeth using a computer-controlled injection system. Quintessence Int 1998; 29(5): 297-303. [PMID: 9693648]

[8] Ran D, Peretz B. Assessing the pain reaction of children receiving periodontal ligament anesthesia using a computerized device (Wand). J Clin Pediatr Dent 2003; 27(3): 247-50. [PMID: 12739685]

[9] Berlin J, Nusstein J, Reader A, Beck M, Weaver J. Efficacy of articaine and lidocaine in a primary intraligamentary injection administered with a computer-controlled local anesthetic delivery system. Oral Surg Oral Med Oral Pathol Oral Radiol Endod 2005; 99(3): 361-6. [http://dx.doi.org/10.1016/j.tripleo.2004.11.009] [PMID: 15716846] 
[10] Higgins JP, Green S. Cochrane handbook for systematic reviews of interventions. Version. 5.1.0, 2015 Available from: www.cochrane-handbook.org [Accessed on 15 Oct 2015].

[11] Moher D, Liberati A, Tetzlaff J, Altman DG. Preferred reporting items for systematic reviews and meta-analyses: the PRISMA statement. J Clin Epidemiol 2009; 62(10): 1006-12.

[http://dx.doi.org/10.1016/j.jclinepi.2009.06.005] [PMID: 19631508]

[12] Klein U, Hunzeker C, Hutfless S, Galloway A. Quality of anesthesia for the maxillary primary anterior segment in pediatric patients: comparison of the P-ASA nerve block using CompuMed delivery system vs traditional supraperiosteal injections. J Dent Child (Chic) 2005; 72(3): 119-25.

[PMID: 16568918]

[13] Loomer PM, Perry DA. Computer-controlled delivery versus syringe delivery of local anesthetic injections for therapeutic scaling and root planing. J Am Dent Assoc 2004; 135(3): 358-65. [http://dx.doi.org/10.14219/jada.archive.2004.0188] [PMID: 15058627]

[14] Yenisey M. Comparison of the pain levels of computer-controlled and conventional anesthesia techniques in prosthodontic treatment. J Appl Oral Sci 2009; 17(5): 414-20. [http://dx.doi.org/10.1590/S1678-77572009000500012] [PMID: 19936518]

[15] Tahmassebi JF, Nikolaou M, Duggal MS. A comparison of pain and anxiety associated with the administration of maxillary local analgesia with Wand and conventional technique. Eur Arch Paediatr Dent 2009; 10(2): 77-82. [http://dx.doi.org/10.1007/BF03321604] [PMID: 19627671]

[16] Kandiah P, Tahmassebi JF. Comparing the onset of maxillary infiltration local anaesthesia and pain experience using the conventional technique vs. the Wand in children. Br Dent J 2012; 213(9): E15. [http://dx.doi.org/10.1038/sj.bdj.2012.988] [PMID: 23138830]

[17] Allen KD, Kotil D, Larzelere RE, Hutfless S, Beiraghi S. Comparison of a computerized anesthesia device with a traditional syringe in preschool children. Pediatr Dent 2002; 24(4): 315-20. [PMID: 12212873]

[18] Flanagan T, Wahl MJ, Schmitt MM, Wahl JA. Size doesn't matter: needle gauge and injection pain. Gen Dent 2007; 55(3): $216-7$. [PMID: 17511363]

[19] de St Georges J. How dentists are judged by patients. Dent Today 2004; 23(8): 96-99, 98-99. [PMID: 15354714]

[20] Proceedings of the $1^{\text {st }}$ Annual Computer-Controlled Local Anesthesia Delivery (C-CLAD) System meeting. Introductory remarks. New Orleans La 2008 .

[21] McArdle BF. Painless palatal anesthesia. J Am Dent Assoc 1997; 128(5): 647. [http://dx.doi.org/10.14219/jada.archive.1997.0265] [PMID: 9150649]

(C) Sivaramakrishnan and Sridharan; Licensee Bentham Open

This is an open access article licensed under the terms of the Creative Commons Attribution-Non-Commercial 4.0 International Public License (CC BY-NC 4.0) (https://creativecommons.org/licenses/by-nc/4.0/legalcode), which permits unrestricted, non-commercial use, distribution and reproduction in any medium, provided the work is properly cited. 